\title{
THE EFFECTIVENESS OF HEALTH PROMOTION TO THE PREGNANT WOMAN'S ATTITUDE IN PREVENTION OF MOTHER TO CHILD HIV TRANMISSION EXAMINATION
}

\author{
Laily Prima Monica \\ Institute Of Health Science Patria Husada Blitar \\ email: lailyprima06@gmail.com
}

\begin{abstract}
PMTCT examination is part of the effort to control HIV and AIDS. The ultimate goal is the babies born to mother with HIV liberated from HIV, maternal and infant alive and healthy. PMTCT general policy in line with the policy of the MCH progam with national program to control HIV, other AIDS (Ministry of Health, 2014). The purpose of this study was to determine the effectiveness of health promotion of the attitude of pregnant woman in PMTCT examination. The research design was pre exsperimental with the approach one group pretest postest design. The sample was 15 pregnant's woman, choosen by total sampling technique at BPM Lilik, SST Sawentar. The result showed that there was an increase in percentage of attitude before and after the treatment with positife attitude from 4 people or $26,7 \%$ to 9 people or $60 \%$. Based on stastical test Wilcoxon sign rank test obtained $p$ value $(0,025)<0,05$, it could be concluded that there were an effect of health promotion to the pregnant woman's attitude in PMTCT examination. Based the research resulth expectable of pregnant woman more active to increase knowledge by obtaining information about the type of pregnant woman examination, especially about PMTCT examination until it can influence their attitude and increase their conscious to make do PMTCT.
\end{abstract}

Keywords: health promotion, attitude, PMTCT examination

Acquired Immunodeficiency Syndrome (AIDS) was first recognized in 1981 and is caused by Human Immunodeficiency Virus (HIV). AIDS is a set of symptoms/clinical signs in people living with HIV due to infection (opportunistic) because of the decline in the immune system. HIV sufferers are easily infected with various diseases because of the immunity of the body is very weak, so the body failed to fight germs that usually do not cause disease. These opportunistic infections can be caused by various viruses, fungi, bacteria and parasites and can attack various organs, including skin, gastrointestinal tract, lungs and brain (Ministri of Health Science RI, 2014).

HIV cases by 2012, cases of HIV/AIDS have spread across 345 out of 497 (69.4\%) districts across the province of Indonesia. The number of new HIV cases each year has reached about 20,000 cases. In 2012 there were 21,511 new cases, of which $57.1 \%$ were $20-39$. years old. The highest source of transmission $(58.7 \%)$ occurs through unsafe sex on heterosexual couples. In 2012 recorded the largest cases of AIDS in the group of housewives $(18.1 \%)$ who, when pregnant, have the potential to transmit HIV infection to their babies. In 2012 also, of 43,624 pregnant women who counseled and tested HIV there were 1,329 (3.05\%) mothers with HIV infection (Ministri of Health Science RI, 2014).

East Java Health Service said, until 2015 East Java ranks second most HIV sufferers in Indonesia with the number of patients 26,235 where 16,051 HIV and AIDS 10184. While Blitar Regency there are 927 people with Gandusari district has the highest HIV patient in Blitar.

More than $90 \%$ of infected infants are infected from HIV positive mothers. Transmission can occur during pregnancy, during labor and during breastfeeding. 
Prevention of mother-to-child HIV transmission (PPIA) is a very effective intervention to prevent transmission (Ministri of Health Science RI, 2014).

PPIA is part of a series of HIV and AIDS control efforts. The ultimate goal is that infants born to mothers with HIV are released from HIV, and mothers and infants remain alive and well. The PPIA's general policy is in line with the national program policies on HIV / AIDS and other STI control, as well as the KIA program policy (Ministri of Health Science RI, 2014).

Most of pregnant women do not understand about PMTCT examination and the function of the examination, they do the examination by order of midwife and not pregnant woman's own wishes.

Preliminary study conducted by researchers in February at BPM Lilik M, S.ST by taking 10 pregnant women, obtained the results of 5 people do not understand the disease HIV / AIDS and not ready to carry out HIV / AIDS, 2 people understand about HIV / AIDS but not ready to do HIV / AIDS examination, and 3 people understand and ready to do HIV / AIDS check.

Based on the preliminary study above, the researcher wanted to conduct a research entitled "The Influence of Health Counseling on Attitudes of Pregnant Women in the Examination of PMTCT in BPM Lilik M Sawentar Village Kanigoro Subdistrict, Blitar Regency"

\section{RESEARCH METHODS}

In this research, the researcher uses pre experimental research design with pre test-post test design approach. This research is done by conducting initial observation (pre test) first before giving intervention, after the intervention is done by final observation (post test). So, this research will seek the influence of health education on the attitude of pregnant women in PMTCT examination in BPM Lilik M Sawentar Village Kanigoro Sub-district, Blitar Regency

The population in this study were all pregnant women in BPM Lilik Sawentar Village Kanigoro District, Blitar regency, which amounted to 15 people. The sampling technique used in this study is the total sampling of sampling technique where the number of samples equals the population.

Data collection techniques used in this study is to provide health education about HIV and PMTCT examination. In this study the instrument used is the Evangelical Events Unit on HIV Disease and
PMTCT Examination and Questionnaire Sheet which contains questions related to the examination of PMTCT.

The statistical test used in this study is wilcoxon sign rank test, is a data analysis technique where not only marks are noticed but also the difference $(\mathrm{X}-\mathrm{Y})$ to determine whether or not the influence.

\section{RESULT}

\section{Characteristics of respondents}

The research was conducted at PM Lilik M, S.ST in Sawentar Village, Kanigoro District, Blitar District. Characteristics of respondents in this study include gender, age, education, occupation, husband work, and pregnancy.

The results show that almost half $(46.7 \%)$ of pregnant women aged 26-30 years, more than half (53.3\%) of mothers have last education that is junior high school, most (80\%) pregnant women have job as housewife, half (53.3\%) husband employed by self-employed pregnant women, and more than half $(53.3 \%)$ were 2 nd pregnancies.

\section{Pre-Treatment Attitudes}

Table 1 Identify the attitudes of pregnant women before treatment

\begin{tabular}{llcc}
\hline No & Category & f & \% \\
\hline 1 & Positive & 4 & 26,7 \\
2 & Negative & 11 & 73,3 \\
\hline & Total & $\mathbf{1 5}$ & $\mathbf{1 0 0}$ \\
\hline
\end{tabular}

Based on Table 1 shows that most (73.3\%) attitude of pregnant women before treatment with health counseling about examination of PMTCT in negative category.

\section{Post-Treatment Attitudes}

Table 2 Identification of pregnant women's post-treatment attitudes

\begin{tabular}{llcc}
\hline No & Category & f & \% \\
\hline 1 & Positive & 9 & 60 \\
2 & Negative & 6 & 40 \\
\hline & Total & $\mathbf{1 5}$ & $\mathbf{1 0 0}$ \\
\hline
\end{tabular}

Based on table 2 shows that most (60\%) attitude of pregnant woman after treatment with health counseling about examination of PMTCT in positive category. 
The influence of health education about PMTCT examination on pregnant woman attitude

Based on Table 3 shows that the increase of percentage of attitude of pregnant women before and after treatment with health counseling about PMTCT examination is attitude with positive category from $26,7 \%$ to $60 \%$

Table 3 Distribution of pregnant women's attitude frequency before and after health counseling about PMTCT examination

\begin{tabular}{llcccc}
\hline No & Category & \multicolumn{2}{c}{ Pre Test } & \multicolumn{2}{c}{ Post Test } \\
\hline 1 & Positive & 4 & $26,7 \%$ & 9 & $60 \%$ \\
2 & Negative & 11 & $73,3 \%$ & 6 & $40 \%$ \\
\hline & Total & $\mathbf{1 5}$ & $\mathbf{1 0 0 \%}$ & $\mathbf{1 5}$ & $\mathbf{1 0 0 \%}$ \\
\hline
\end{tabular}

Wilcoxon Sign Rank Test p value: 0,025

Based on statistical test Wlicoxon Signed Rank Test got $p$ value $=0,025$, so $p$ value $=0,025<\alpha=$ 0,05 which means showing the influence of health education about examination of PMTCT to attitude of pregnant mother.

\section{DISCUSSION}

\section{Attitude Of Respondents Before Health Coun- seling About PMTCT Examination}

The results showed that from 15 respondents, 73.3\% of respondents before doing health education have a negative attitude about PMTCT examination. A person's attitude toward an object is a favorable or favorable feeling or an unfavorable feeling to the object. Factors that influence attitudes include internal factors that are factors that are in the person concerned such as selectivity and personal experience and external factors that are outside the human or environmental factors (Azwar, 2011). Negative attitude here means there is no awareness or desire of respondents to conduct PMTCT examination. Respondents tend to agree not to carry out the examination for fear that it may harm him and consider the examination only necessary for risky pregnant women only. This negative attitude of the respondent is allegedly influenced by the environment and the work of the respondents, which makes the expectant mother susceptible to the views of others who do not like the examination.

Based on the results of the study found that $80 \%$ of respondents are housewives. The formation of an attitude depends on the culture in which the individual is brought up. The environment provides the first social influence for a person, where one can learn good things, also bad things depending on the nature of the group (Azwar, 2011). Should be a housewife has a loose time so it can take time to learn things that are good for him. However, respondents also have a social environment that is family and also neighbors around the dwelling. Respondents see that their former neighbors during pregnancy did not conduct PMTCT examinations so they were also affected not to conduct PMTCT examinations for fear that such checks could harm themselves. The environment is a social influence for a person, where one can learn good things as well as bad things depending on the nature of the group. In the environment, one will gain experience that will affect the way of thinking.

In addition, the negative attitudes of these respondents were also supported by a strong respondent's tendency in the cognitive component, thus affecting the affective and conative components owned by the respondents. Attitude is as a certain order in terms of feeling (affective), thinking (cognitive), and predisposing a person's (konatif) action to an aspect in the surrounding environment (Azwar, 2011). The cognitive component contains a person's beliefs about what applies or what is right about the object of attitude. The affective component involves one's subjective emotional problem of an attitude object. Behavioral component or conative component in attitude structure shows how behavior or tendency to behave that exists in a person related to the object of his attitude. Respondents have a poor belief in PMTCT examination because they consider the examination unimportant and self-defeating so that it affects the feelings and also the respondent's behavior for not conducting the PMTCT examination.

\section{Attitude Of Respondents After Health Coun- seling About PMTCT Examination}

The results showed that from 15 respondents, $60 \%$ of respondents have a positive attitude in PMTCT examination. Changes in attitude can occur slowly with increasing information and experience gained. The information comes from health counseling, health education is a process of improving public knowledge about health, accompanied by efforts to facilitate behavior change and is a health program designed to bring improvement or change 
in individuals, communities and the environment. This is in accordance with Azwar (2011) that the formation of attitudes can be influenced by several factors namely education, experience, influence of others who are considered important, emotional factors and mass media.

Based on the results of the study found that $53.3 \%$ of respondents have junior high school education. Education is an activity or learning process to develop or improve certain skills so that the target of education can stand alone. The level of education also determines whether or not someone absorbs and understands the information they get. Education means the guidance given by a person towards the development of others toward a particular goal. The understanding of good and bad, wrong or right, that determines one's belief system to play a role in determining one's attitude (Azwar, 2011). By having adequate education, respondents will more easily receive information so that they can understand and have the confidence to conduct PMTCT examination.

Based on the results of the study found $46.7 \%$ of respondents aged 26-30 years. In order to form the basis for attitude formation, personal experience must leave a strong impression. Therefore attitude will be easily formed. Personal experience will shape and influence one's appreciation of social stimuli (Azwar, 2011). With the maturity of the age of respondents will further improve the experience of someone in doing something that is best for him. Provision of health education is one thing that can leave a strong impression to the respondent, so that respondents will be able to conduct PMTCT examination of self-awareness.

Attitudes of respondents in this study after being given a health education is still negative. One characteristic of attitude is spontaneity, which concerns the extent to which individual readiness to express his attitude spontaneously (Azwar, 2011). Providing health education that only a few minutes certainly can not grow a positive attitude to the respondents who previously had a negative attitude spontaneously when the measurement of attitude done in this study. To change a person's attitude takes a short time. Provision of health education will improve a person's understanding of PMTCT examination appropriately. This negative attitude is supported by the cognitive, affective and conative components that exist in the respondent's self regarding the PMTCT examination.

\section{Influence Between Health Counseling On At- titude}

Based on the results of the study found that $73.3 \%$ of respondents were negative before the health counseling and $60 \%$ of respondents positive attitude after health education about PMTCT examination. There is a change of attitude of respondents from negative attitude to positive attitude $33,3 \%$.

Based on Wilcoxon statistical test obtained sig value $=0,025$. This shows that there is influence of health education about PMTCT examination to respondent attitude. But there are still $40 \%$ of respondents who still have negative attitude after health counseling, this is caused by work, ligkungan and acceptance in health education about PMTCT examination conducted by researcher.

Health education is an attempt to motivate or coordinate goals so that they behave in accordance with the guidance of health values (Notoatmodjo, 2011). The success of a health counseling may be influenced by extension, targeting and counseling processes. A good health counseling will certainly be able to change a person's behavior to do the best for health. However, in the PMTCT examination it is necessary to have the nearest service facility providing the service so as not to burden the pregnant mother in conducting PMTCT examination.

\section{CONCLUSIONS AND SUGGESTIONS}

\section{Conclusions}

Based on the results of research conducted it can be drawn conclusions as follows: 1) The attitude of respondents before health counseling about PMTCT examination showed most $(73,3 \%)$ have negative attitude and $26,7 \%$ have positive attitude; 2) Attitude of respondents after health counseling about PMTCT examination showed most $(60 \%)$ have positive attitude and $40 \%$ have negative attitude; 3) There is influence of health education about examination of PMTCT on attitude of respondent with $\mathrm{p}$ value equal to 0,025

\section{Suggestions}

In accordance with the conclusions that have been proposed, researchers want to give some suggestions as follows: 1) For Researchers, It is expected to add insight and experience of the author in applying the science of PMTCT examination that 
has been obtained during the education at STIKes Patria Husada Blitar majoring in midwifery; 2) For Educational Institutions, It is hoped that the results of this research can be used as documentation of the library, provide additional information to complement the library materials, and for other students who want to know more clearly about the PMTCT examination; 3) For Research Sites, It is expected to be an information and input for the community, especially pregnant women so they become aware and willing to conduct PMTCT examination based on his own desire

\section{REFERENCES}

Azwar. 2011. Pengukuran Sikap. Jakarta: Rineka Cipta Kemenkes RI. 2014. Pedoman Pelaksanaan Pencegahan Penularan HIV dan Sifilis dari Ibu ke Anak bagi Tenaga Kesehatan. Jakarta: Kemenkes RI.

Notoatmodjo, S. 2011. Promosi Kesehatan Teori \& Aplikasi. Jakarta: Rineka Cipta. 